\title{
Human herpesvirus 6 is associated with status epilepticus and hyponatremia after umbilical cord blood transplantation
}

\author{
Fernanda Leite de Souza Franceschi $M D^{1,5}$, Jaime Green $M D^{2}$, Zuzan Cayci $M D^{3}$, Evan Mariash $\mathrm{MD}^{1}$, \\ Mustapha Ezzeddine MD , Veronika Bachanova MD ${ }^{1}$, Celalettin Ustun MD ${ }^{1}$
}

FL de Souza Franceschi, J Green, Z Cayci, et al. Human herpesvirus 6 is associated with status epilepticus and hyponatremia after umbilical cord blood transplantation. Can J Infect Dis Med Microbiol 2014;25(3):170-172.

Status epilepticus after allogeneic hematopoietic cell transplantation (alloHCT) is rare. The authors report a case involving a 65-year-old man with nonconvulsive status epilepticus 34 days after umbilical cord blood transplantion for chronic lymphocytic leukemia. Cerebrospinal fluid and serum were positive for human herpesvirus 6 (HHV6). Magnetic resonance imaging of the brain showed symmetric T2 hyperintensity bilaterally in the mesial temporal lobes, and T2 hyperintensities and restricted diffusion of bilateral putamina. Despite aggressive anticonvulsive therapy, his seizures only abated with initiation of ganciclovir therapy. The patient completed six weeks of combination antiviral therapy (ganciclovir and foscarnet). His cognitive function gradually improved and, after prolonged rehabilitation, the patient was discharged home with residual intermittent memory loss but otherwise functional. HHV6 should be considered in the differential diagnosis of nonconvulsive status epilepticus after alloHCT, especially in patients with hyponatremia. Empirical antiviral therapy targeting HHV6 should be administered to these patients.

Key Words: Human herpesvirus 6; Hyponatremia; Immunocompromised host; Status epilepticus; Umbilical cord blood transplantation

\section{CASE PRESENTATION}

A 59-year-old man was diagnosed with chronic lymphocytic leukemia (CLL) in 2007 and managed with various chemotherapy drugs (fludarabine, alemtuzumab, bendamustine, cyclophosphamide, doxorubicin, vincristine, prednisone and rituximab). However, the patient required umbilical cord blood transplantation following a reduced intensity conditioning regimen (cyclophosphamide $50 \mathrm{mg} / \mathrm{kg}$ on day -6 , fludarabine $40 \mathrm{mg} / \mathrm{m}^{2}$ daily from days -6 through -2 and total body irradiation $200 \mathrm{cGy}$ on day -1) for treatment of resistant CLL in February 2013. Graft-versus-host disease prophylaxis comprised sirolimus $4 \mathrm{mg}$ daily and mycophenolate mofetil (1500 mg twice per day from days -3 through +30$)$. Cytomegalovirus immunoglobulin $(\mathrm{Ig}) \mathrm{G}$ and herpes simplex virus IgG were positive, whereas Epstein-Barr virus (EBV) IgG was negative. Infection prophylaxis based on internal hospital guidelines included levofloxacin (250 mg daily), voriconazole (200 mg twice per day for possible invasive fungal infection due to lung nodules before allogeneic hematopoietic cell transplantation [alloHCT]), high-dose acyclovir ( $800 \mathrm{mg}$ five times per day), and
L'herpèsvirus humain type 6 s'associe à un état de mal épileptique et à une hyponatrémie après la greffe de sang de cordon

Létat de mal épileptique est rare après une greffe de cellules souches hématopoïétiques allogéniques (GCSallo). Les auteurs rendent compte du cas d'un homme de 65 ans présentant un état de mal épileptique non convulsif 34 jours après avoir subi une greffe de sang de cordon pour soigner une leucémie lymphocytaire chronique. Le liquide céphalorachidien et le sérum étaient positifs à l'herpèsvirus humain type 6 (HVH6). L'imagerie par résonance magnétique du cerveau a révélé un signal hyperintense symétrique et bilatéral des lobes temporaux mésiaux en T2, ainsi que des signaux hyperintenses en T2 et une diffusion bilatérale restreinte du putamen. Malgré un traitement énergique aux anticonvulsivants, les convulsions n'ont diminué qu'après l'amorce d'un traitement au ganciclovir. Le patient a été mis sous bithérapie antivirale (ganciclovir et foscarnet) pendant six semaines. Sa fonction cognitive s'est améliorée graduellement et, après une réadaptation prolongée, il a obtenu son congé à domicile. Il présentait une perte de mémoire résiduelle intermittente, mais était autrement fonctionnel. Il faut envisager un HVH6 dans le diagnostic différentiel de l'état de mal épileptique non convulsif après une GCSallo, particulièrement chez les patients présentant une hyponatrémie. Il faut administrer une antivirothérapie empirique qui cible l'HVH6 chez ces patients.

\footnotetext{
${ }^{1}$ Division of Hematology-Oncology and Transplantation; ${ }^{2}$ Division of Infectious Disease, Department of Medicine; ${ }^{3}$ Department of Radiology; ${ }^{4}$ Department of Neurology, University of Minnesota, Minneapolis, Minnesota, USA; ${ }^{5}$ Department of Hematology-Oncology, Amaral Carvalho Hospital, Jau, Sao Paulo, Brazil

Correspondence: Dr Celalettin Ustun, Division of Hematology Oncology and Transplantation, Department of Medicine, University of Minnesota, 14-142 PWB, 516 Delaware Street Southeast, Minneapolis, Minnesota 55455, USA. Telephone 612-624-0123, fax 612-625-6919, e-mail custun@umn.edu
} 


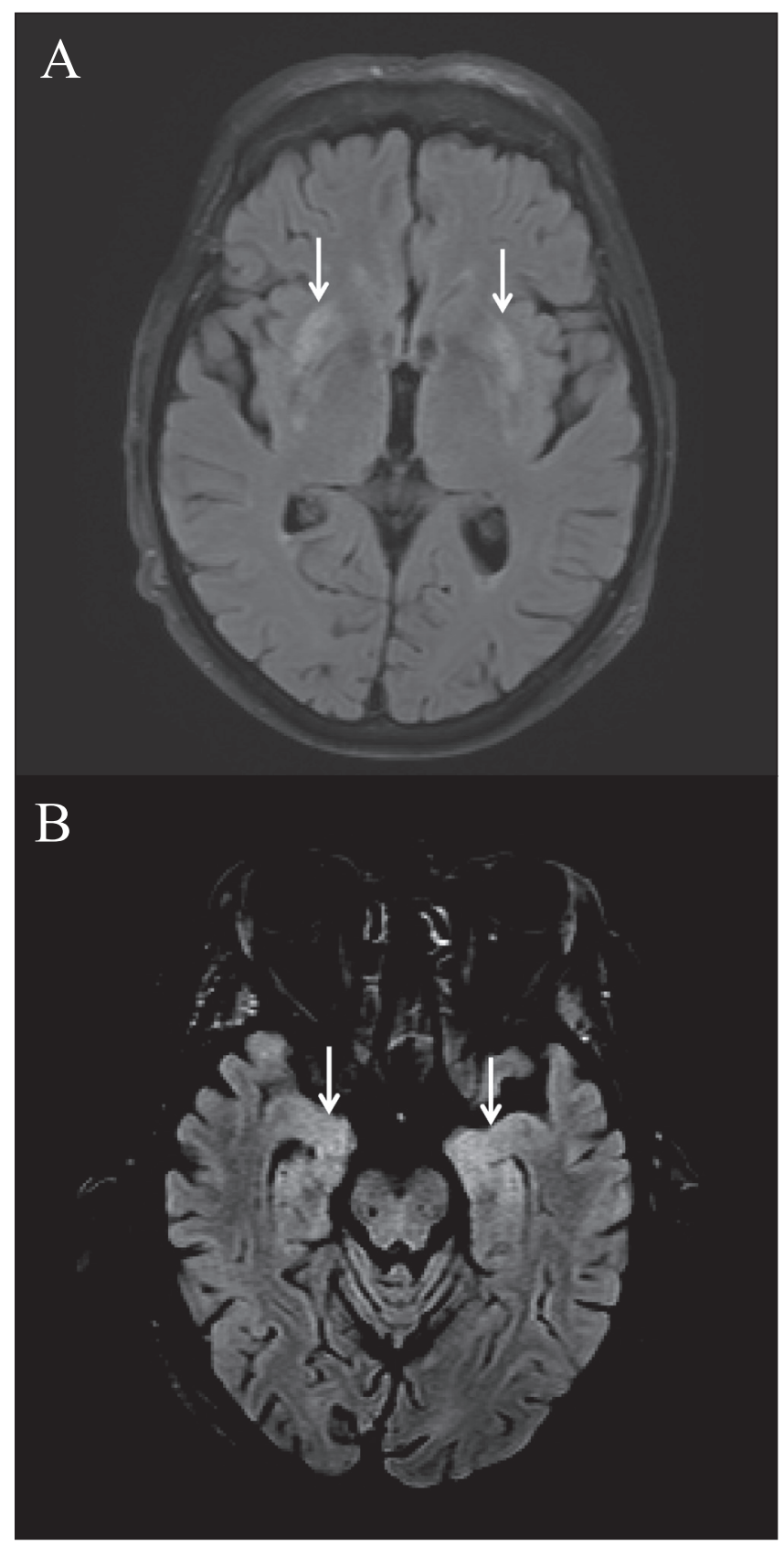

Figure 1) Axial fluid-attenuated inversion recovery-weighted sequence demonstrating hyperintense signal along bilateral putamina (A) and medial temporal lobes (B) (arrows)

(MRI) of the brain were normal for his age. Cerebrospinal fluid (CSF) analysis showed five white blood cells (comprised of lymphocytes and monocytes), no malignant cells, normal protein level (360 g/L) and normal glucose level $(4.628 \mathrm{mmol} / \mathrm{L})$. CSF evaluation, including bacterial and fungal cultures, Gram stain, India ink and viral studies (cytomegalovirus, EBV, John Cunningham virus, herpes simplex virus and herpes zoster virus polymerase chain reactions) were all negative.

Despite aggressive antiepileptic therapy (phenytoin $250 \mathrm{mg}$ twice per day and levetiracetam $2 \mathrm{~g}$ twice per day), electroencephalography continued to show a pattern of acute repetitive seizures in the right and left frontotemporal regions. High-dose midazolam drip $(10 \mathrm{mg} / \mathrm{h})$ was added for seizure control. A repeat MRI on hospital day 5 showed a symmetric hyperintensity bilaterally at the basal ganglia and subtle hypertensities in bilateral mesial temporal lobes (Figure 1). CSF test results for human herpesvirus 6 (HHV6) were available and positive
$(379,300$ copies $/ \mathrm{mL})$ on day +41 . The concurrent serum sample was also positive for HHV6 (8000 copies/mL). Ganciclovir ( $5 \mathrm{mg} / \mathrm{kg}$ intravenous twice per day) was started due to no improvement in his clinical condition, seizure activity and the evolving MRI findings. Seizure activity was no longer detectable, and the patient had become alert and was extubated on day +43 . A long hospitalization ensued, which was complicated by deconditioning and multiple reintubations for hypercapnea and respiratory muscle weakness. He completed six weeks of ganciclovir therapy $(5 \mathrm{mg} / \mathrm{kg}$ twice per day). Foscarnet was added for positive isolation of HHV6 from bronchoalveolar lavage. His cognitive function gradually improved with prolonged rehabilitation. He is now at home with residual intermittent memory loss but otherwise functional.

\section{DISCUSSION}

Alteration in consciousness and seizure after alloHCT can be caused by posterior reversible encephalopathy syndrome, immunosuppressive drug toxicities, fludarabine toxicity, transplantation-associated thrombotic microangiopathy or central nervous system infections, including HHV6 (1-3). HHV6, a beta herpes virus, infects $95 \%$ of the population by two years of age and is the cause of exanthema subitum (4). After acute infection, HHV6 remains in a latent form in CD34 ${ }^{+}$cells, monocytes and macrophages. On average, $50 \%$ of alloHCT recipients - possibly more frequent in umbilical cord blood transplant patients will reactivate HHV6 in the first month of alloHCT (range two to eight weeks) (5-10). Although the direct causative effect has never been confirmed, HHV6 reactivation is associated with several clinical syndromes, including febrile illness, delayed engraftment, pneumonitis and encephalitis after alloHCT (4,7,9-12). Among these syndromes, there has been accumulating evidence supporting a causal association between HHV6 and encephalitis (4). Moreover, autopsy findings are also suggestive of a pathogenic role for HHV6 (13).

Diagnosis of HHV6-associated encephalitis can be complicated. Patients can present with acute mental status changes, cognitive dysfunction, delirium, hallucinations, anterograde amnesia and seizure (12,14-17). Hyponatremia, resulting from the syndrome of inappropriate antidiuretic hormone secretion or sodium wasting in urine, can be observed $(3,12,18)$. Normal or mildly elevated protein levels and mild pleocytosis are typical CSF findings $(5,12)$. Brain MRI has a role in narrowing the differential diagnosis to limbic encephalitis. It shows T2 hyperintense signal abnormality of one or both hippocampi and variably involving adjacent medial temporal lobe structures of the limbic system, including amygdalae and parahippocampal gyri (limbic encephalitis) $(12,14)$. In addition to HHV6 encephalitis, the differential diagnosis of these findings includes other infectious causes of encephalitis such as herpes zoster virus, varicella zoster virus, cytomegalovirus, EBV or neurosyphilis, autoimmune disorders, conditioning regimen toxicity and paraneoplastic syndromes (19). In vitro and limited clinical data support the antiviral effect of foscarnet and ganciclovir against HHV6 $(4,20)$. The recommended duration of therapy is at least three weeks. Although survival rates appear to be improving, HHV6 encephalitis remains associated with mortality and morbidity (long-term sequelae, such as neuropsychological disorders, are not uncommon) $(6,21,22)$.

HHV6 should be considered in patients with nonconvulsive status epilepticus presenting with sudden unconsciousness after alloHCT. No other apparent cause of seizure and the presence of hyponatremia increase the likelihood of HHV6 infection. Patients should be treated with HHV6-effective empirical antiviral therapy.

DISCLOSURES: The authors have no financial disclosures or conflicts of interest to declare.

\section{REFERENCES}

1. Saiz A, Graus F. Neurologic complications of hematopoietic cell transplantation. Semin Neurol 2010;30:287-95.

2. Beitinjaneh A, McKinney AM, Cao Q, Weisdorf DJ.

Toxic leukoencephalopathy following fludarabine-associated hematopoietic cell transplantation. Biol Blood Marrow Transpl 2011;17:300-8 
3. Zerr DM, Gooley TA, Yeung L, et al. Human herpesvirus 6 reactivation and encephalitis in allogeneic bone marrow transplant recipients. Clin Infect Dis 2001;33:763-71.

4. Zerr DM. Human herpesvirus 6 (HHV-6) disease in the setting of transplantation. Curr Opin Infect Dis 2012;25:438-44.

5. Zerr DM, Gupta D, Huang ML, Carter R, Corey L. Effect of antivirals on human herpesvirus 6 replication in hematopoietic stem cell transplant recipients. Clin Infect Dis 2002;34:309-17.

6. Sakai R, Kanamori H, Motohashi K, et al. Long-term outcome of human herpesvirus- 6 encephalitis after allogeneic stem cell transplantation. Biol Blood Marrow Transpl 2011;17:1389-94.

7. Betts BC, Young JA, Ustun C, Cao Q, Weisdorf DJ. Human herpesvirus 6 infection after hematopoietic cell transplantation: Is routine surveillance necessary? Biol Blood Marrow Transpl 2011;17:1562-8.

8. Ljungman P, Singh N. Human herpesvirus-6 infection in solid organ and stem cell transplant recipients. J Clin Virol 2006;37(Suppl 1):S87-91.

9. Zerr DM, Corey L, Kim HW, Huang ML, Nguy L, Boeckh M. Clinical outcomes of human herpesvirus 6 reactivation after hematopoietic stem cell transplantation. Clin Infect Dis 2005;40:932-40.

10. Chevallier P, Hebia-Fellah I, Planche L, et al. Human herpes virus 6 infection is a hallmark of cord blood transplant in adults and may participate to delayed engraftment: A comparison with matched unrelated donors as stem cell source. Bone Marrow Transpl 2010;45:1204-11.

11. Ljungman P, Wang FZ, Clark DA, et al. High levels of human herpesvirus 6 DNA in peripheral blood leucocytes are correlated to platelet engraftment and disease in allogeneic stem cell transplant patients. Br J Haematol 2000;111:774-81.

12. Seeley WW, Marty FM, Holmes TM, et al. Post-transplant acute limbic encephalitis - clinical features and relationship to HHV6. Neurology 2007;69:156-65.

13. Shintaku M, Kaneda D, Tada K, Katano H, Sata T. Human herpes virus 6 encephalomyelitis after bone marrow transplantation: Report of an autopsy case. Neuropathology 2010;30:50-5.
14. Howell KB, Tiedemann K, Haeusler G, et al. Symptomatic generalized epilepsy after HHV6 posttransplant acute limbic encephalitis in children. Epilepsia 2012;53:e122-6.

15. Zerr DM, Fann JR, Breiger D, et al. HHV-6 reactivation and its effect on delirium and cognitive functioning in hematopoietic cell transplantation recipients. Blood 2011;117:5243-9.

16. Raspall-Chaure M, Armangue T, Elorza I, Sanchez-Montanez A, Vicente-Rasoamalala M, Macaya A. Epileptic encephalopathy after HHV6 post-transplant acute limbic encephalitis in children: Confirmation of a new epilepsy syndrome. Epilepsy Res 2013;105:419-22.

17. Provenzale JM, van Landingham K, White LE. Clinical and imaging findings suggesting human herpesvirus 6 encephalitis. Pediatr Neurol 2010;42:32-9.

18. Kawaguchi T, Takeuchi M, Kawajiri C, et al. Severe hyponatremia caused by syndrome of inappropriate secretion of antidiuretic hormone developed as initial manifestation of human herpesvirus-6associated acute limbic encephalitis after unrelated bone marrow transplantation. Transpl Infect Dis 2013;15:E54-7.

19. Thuerl C, Muller K, Laubenberger J, Volk B, Langer M. MR imaging of autopsy-proved paraneoplastic limbic encephalitis in non-Hodgkin lymphoma. Am J Neuroradiol 2003;24:507-11.

20. De Bolle L, Naesens L, De Clercq E. Update on human herpesvirus 6 biology, clinical features, and therapy. Clin Microbiol Rev 2005; 18:217-45

21. Yamane A, Mori T, Suzuki S, et al. Risk factors for developing human herpesvirus 6 (HHV-6) reactivation after allogeneic hematopoietic stem cell transplantation and its association with central nervous system disorders. Biol Blood Marrow Transpl 2007;13:100-6.

22. Zerr DM, Corey L, Kim HW, Huang ML, Nguy L, Boeckh M. Clinical outcomes of human herpesvirus 6 reactivation after hematopoietic stem cell transplantation. Clin Infect Dis 2005;40:932-40. 


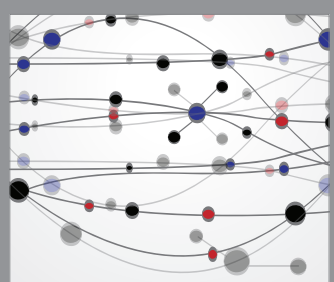

The Scientific World Journal
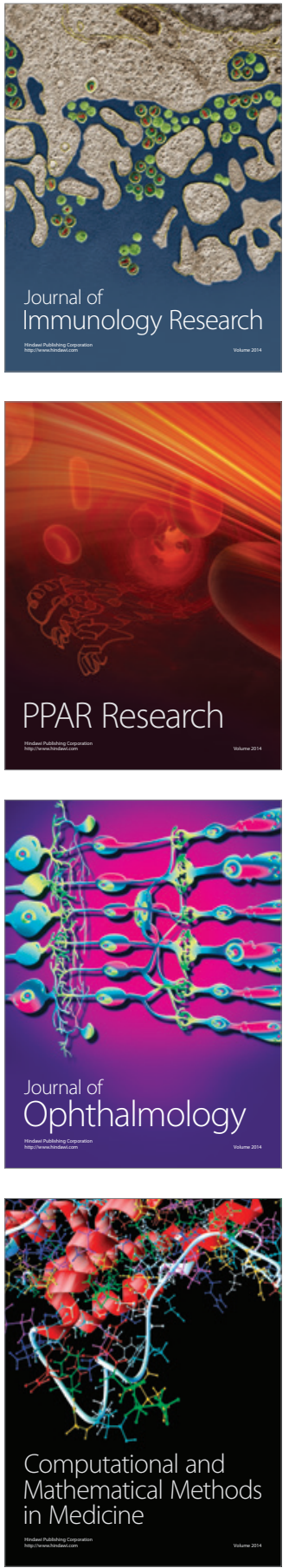

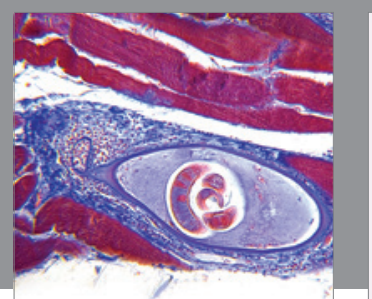

Gastroenterology Research and Practice

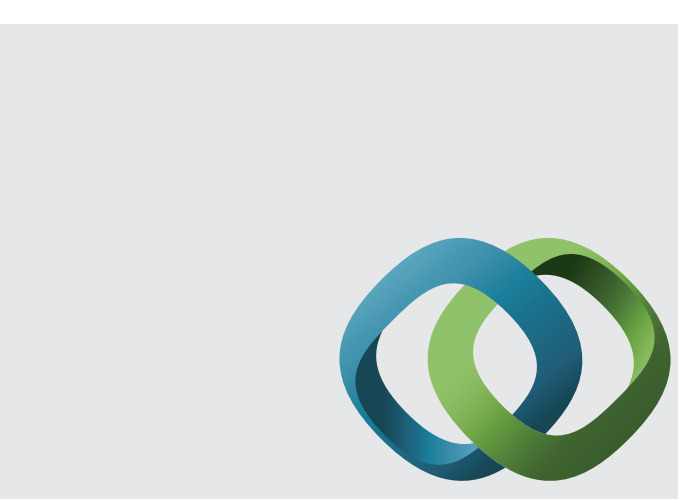

\section{Hindawi}

Submit your manuscripts at

http://www.hindawi.com
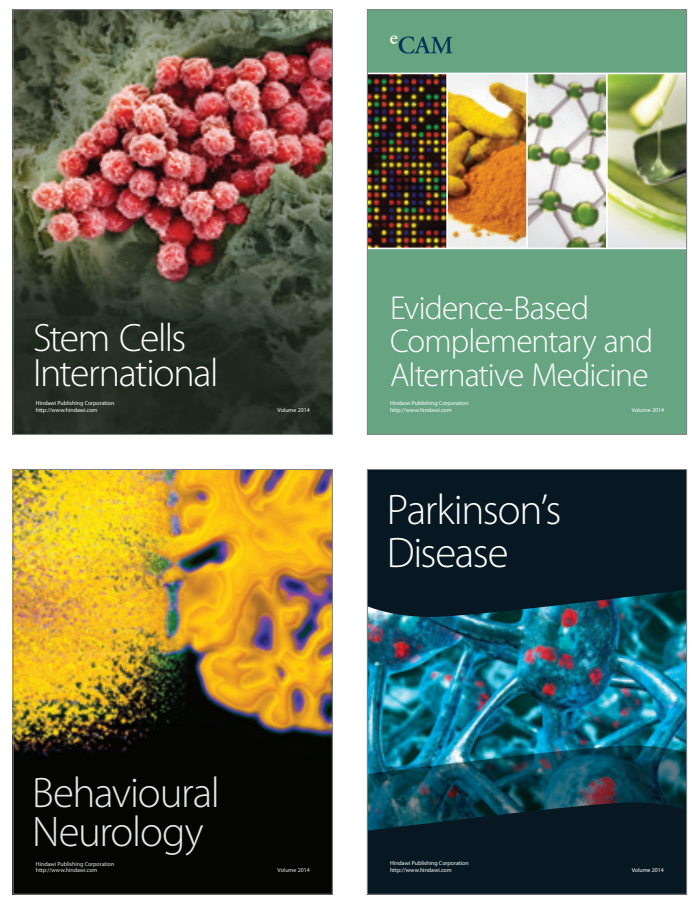
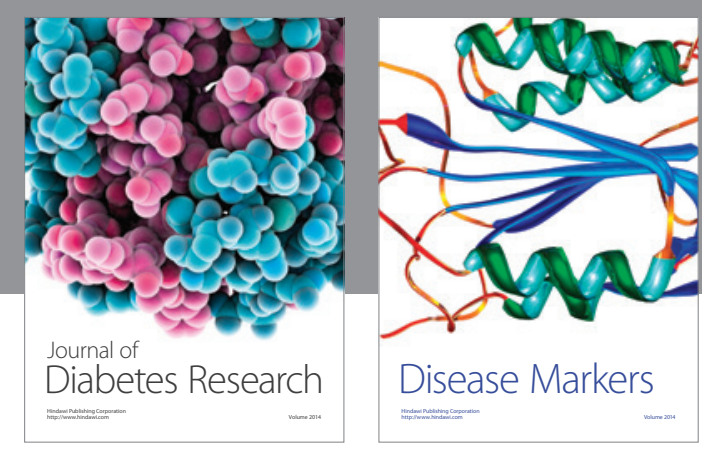

Disease Markers
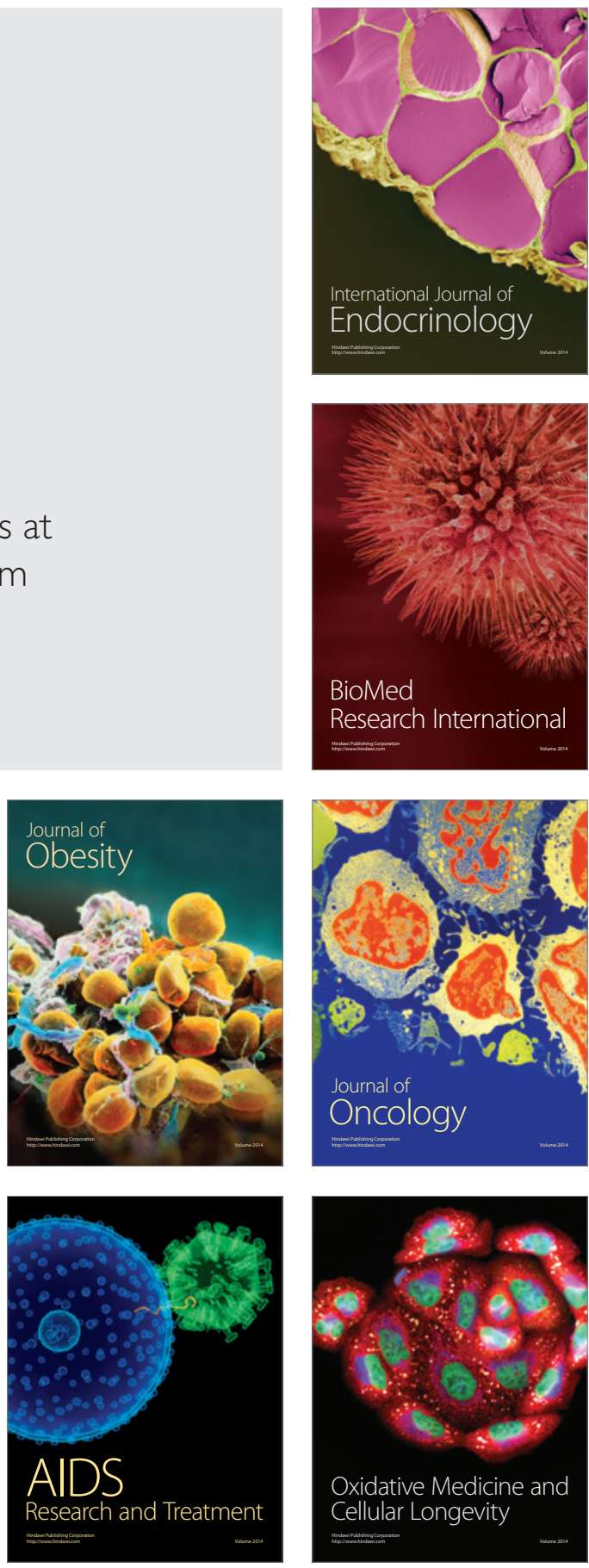